\title{
THERMODYNAMIC PROPERTIES OF SORPTION OF RICE IN THE HUSK
}

\author{
Juliana S. Zeymer ${ }^{1 *}$, Paulo C. Corrêa ${ }^{2}$, Gabriel H. H. de Oliveira ${ }^{3}$, Fernanda M. Baptestini ${ }^{4}$, \\ Igor L. Faria ${ }^{2}$
}

\author{
${ }^{1 *}$ Corresponding author. Universidade Federal de Viçosa/ Viçosa - MG, Brasil. E-mail: juliana.zeymer@ufv.br
}

\section{KEYWORDS \\ equilibrium moisture content, integral isosteric heat of sorption, differential entropy, Gibbs free energy, enthalpy- entropy compensation theory.}

\begin{abstract}
This study aimed to determine the thermodynamic properties of sorption processes (desorption and adsorption) of rice in the husk, cv. Urucuia. A static-gravimetric method was used to reach equilibrium moisture content at different temperatures $(10,20,30,40$, and $50{ }^{\circ} \mathrm{C} \pm 1{ }^{\circ} \mathrm{C}$ ) and relative humidity levels $(10,30,50,70$, and $90 \% \pm 2 \%)$. A decrease in moisture content led to an increment of the integral isosteric heat of sorption, indicating a higher demand for energy to remove moisture from the product. Differential entropy of sorption decreased along with a moisture content increment, with higher values for desorption. This indicates a higher mobility of water molecules during desorption if compared to adsorption. Gibbs free energy decreased with increasing temperature in both processes, with positive values for desorption (endothermic process), and negative for adsorption (exothermic process). The enthalpy-entropy compensation theory is valid for both sorption phenomena (desorption and adsorption) of rice in the husk, being both processes enthalpy controlled.
\end{abstract}

\section{INTRODUCTION}

Rice is one of the most produced and consumed cereals worldwide and the primary source of food for more than half of the world population (Mingotte et al., 2012). This grain is an excellent source of energy due to its high starch content, along with proteins, minerals, and vitamins, besides its low lipid content (Walter et al., 2008).

This cereal has a particular emphasis on developing countries, such as Brazil, and plays a strategic role in food safety issues. Given that, certain aspects related to its production and consumption must be continuously monitored and evaluated to ensure its nutritional value (Lima et al., 2015). Thus, the scientific research on thermodynamic properties of agricultural products should be improved, correlating the factors affecting food quality with the interaction between water and chemical compounds in products.

Thermodynamics has been a source of information on the designing of drying equipment. Through this study, it is possible to calculate the energy demands of a process, investigate the properties of adsorbed water, evaluate microstructures, and assess physical phenomena occurring on food surface (Corrêa et al., 2012). Furthermore, thermodynamic properties can be described by sorption isotherms (desorption and adsorption), facilitating its interpretation.

Enthalpy alterations provide a measure of changes in energy occurring between water molecules and a sorbent material during sorption processes. While entropy is associated with attraction or repulsion forces within a system, being related to the water-sorbent spatial arrangement. In this sense, entropy characterizes the degree of order or disorder in a water-sorbent system (McMinn et al., 2005).

In turn, Gibbs free energy indicates the energy spontaneity of a water-sorbent interaction, providing a measure of energy availability in the reaction. Negative values indicate a spontaneous process, whereas positive ones point to a non-spontaneous process (Rizvi, 1995).

Enthalpy-entropy compensation theory is a tool to recognize the different mechanisms of water sorption under different conditions (Rizvi, 1995). This theory states that compensation arises from changes in the nature of solvent-solute interactions, enthalpy and entropy have a linear relationship, and the slope of the curve corresponds to the isokinetic temperature at which all reactions occur at the same pace (Moreira et al., 2008).

\footnotetext{
${ }^{2}$ Universidade Federal de Viçosa/ Viçosa - MG, Brasil.

${ }^{3}$ Instituto Federal do Sudeste de Minas Gerais/ Manhuaçu - MG, Brasil.

${ }^{4}$ Universidade Federal do Espírito Santo/ Alegre - ES, Brasil.

Received in: 6-29-2017

Accepted in: 2-26-2018
} 
In the past years, different studies have been carried out to determine the thermodynamic properties of water sorption in different grains, such as soybeans (Oliveira et al., 2013a), sorghum (Resende et al., 2014), coffee (Corrêa et al., 2016), castor beans (Goneli et al., 2016), common beans, and chickpeas (Shafaei et al., 2016).

Given the above and the importance of theoretical knowledge on the interaction between water and rice in the husk, the objective of this study was to determine and evaluate the water sorption thermodynamics (desorption and adsorption) of rice in the husk as a function of equilibrium moisture content.

\section{MATERIAL AND METHODS}

The study was conducted at the Laboratory of Physical Properties and Quality of Agricultural Products, National Center for Storage Training (CENTREINAR), which is located in the Federal University of Viçosa, in Viçosa - MG, Brazil.

Grains of irrigated rice in the husk, cultivar Urucuia, were obtained from an experimental farm of EPAMIG, in the south of Minas Gerais state. These grains were manually collected with an initial moisture content of nearly 0.28 (d.b.) and then used for desorption process. For adsorption process, the grains were dehydrated in an oven with forced air circulation (model 400-3ND/Gehaka brand) at a temperature of $40{ }^{\circ} \mathrm{C}$, until a final moisture content of 0.17 (d.b.).

For equilibrium moisture content of rice in the husk in both processes, a static method was employed (Brasil, 2009) at different temperatures $(10,20,30,40$, and $50 \pm 1$ $\left.{ }^{\circ} \mathrm{C}\right)$ and relative humidity levels $(10,30,50,70$, and $90 \%$ $\pm 2 \%$ ). Such temperature and relative humidity conditions were adopted because of the ranges found in riceproducing countries, where storage of this product may occur at different seasons of the year and, therefore, showing a wide range of conditions. The temperature was controlled by keeping the grains in BOD chambers (model 347 CD/FANEM brand); while relative humidity was managed by using saturated salt solutions. Each sample consisted of 15-g grain samples, in five repetitions.

During the process, samples were periodically weighed on an analytical scale (model AY220/ MARTE brand), reaching a hygroscopic equilibrium when the mass remained invariable for three consecutive measurements. Moisture content was determined by the gravimetric method, using an oven with forced air circulation at $105 \pm$ $1^{\circ} \mathrm{C}$ for $24 \mathrm{~h}$, in three repetitions, according to Brasil (2009).

In a previous study (submitted but not yet published), sorption isotherms for rice in the husk were mathematically modeled (data not shown). Among Modified Henderson, Modified Halsey, Modified Oswin, Copace, Sigma-Copace, Smith and Harkins Jura models, the Chung-Pfost one best represented the experimental data. This model presented determination coefficients of 99.60 and $99.64 \%$, standard deviation of 0.49 and 0.45 (d.b.), mean relative error of 5.16 and $5.99 \%$, besides a random distribution of residues for both desorption and adsorption processes, respectively. The present study aims to identify the thermodynamic properties of water sorption of rice in the husk, comparing desorption and adsorption processes. Thus, this study will not present data regarding the analysis of the aforementioned models.
Using the Chung-Pfost model, values of water activity were obtained for desorption and adsorption processes, as shown in eqs (1) and (2), respectively:

$\mathrm{U}_{\mathrm{e}}=37.41336^{* *}-6.23300^{* *} \ln \left[-\left(\mathrm{T}+49.64237^{* *}\right) \ln \mathrm{a}_{\mathrm{w}}\right]$

$U_{e}=35.93677^{* *}-6.08728^{* *} \ln \left[-\left(T+50.48370^{* *}\right) \ln a_{w}\right]$

** Significant at $5 \%$ probability by the "t" test

In which:

$\mathrm{U}_{\mathrm{e}}$ - equilibrium moisture content, \% d.b.;

$\mathrm{a}_{\mathrm{w}}-$ water activity, decimal, and

$\mathrm{T}$ - temperature, ${ }^{\circ} \mathrm{C}$.

The thermodynamic properties [entropy $(\Delta \mathrm{S})$, enthalpy $(\Delta H)$, Gibbs free energy $(\Delta G)$ and enthalpyentropy compensation theory] were obtained using the method described by Corrêa et al. (2012):

$$
\begin{aligned}
& {\ln a_{W}}= \pm\left(\frac{\Delta H_{s t}}{R T}-\frac{\Delta S}{R}\right) \\
& \Delta H=\Delta H_{s t}-\Delta H_{\text {vap }} \\
& \Delta G= \pm R T \ln a_{W} \\
& T_{B}=\widehat{T}_{B} \pm t_{m-2, \alpha} / \mathbf{z} \sqrt{V_{a r}\left(T_{B}\right)} \\
& T_{h m}=\frac{n}{\sum_{i=1}^{\mathrm{n}}\left(\frac{1}{T_{i}}\right)}
\end{aligned}
$$

In which:

$\Delta \mathrm{H}$ - isosteric heat of sorption or differential enthalpy, $\mathrm{kJ} \mathrm{kg}^{-1}$;

$\mathrm{R}$ - universal gas constant, $0.462 \mathrm{~kJ} \mathrm{~kg}^{-1} \mathrm{~K}^{-1}$;

$\Delta \mathrm{H}_{\mathrm{vap}}$ - latent heat of vaporization of pure water, $\mathrm{kJ} \mathrm{kg}^{-1}$;

$\Delta \mathrm{H}_{\mathrm{st}}-$ net isosteric heat of sorption, $\mathrm{kJ} \mathrm{kg}^{-1}$;

$\Delta \mathrm{S}$ - differential entropy of sorption, $\mathrm{kJ} \mathrm{kg}^{-1} \mathrm{~K}^{-1}$;

$\Delta \mathrm{G}-\mathrm{Gibbs}$ free energy, $\mathrm{kJ} \mathrm{kg}^{-1} \mathrm{~mol}^{-1}$;

$\mathrm{T}_{\mathrm{B}}$ - isokinetic temperature, $\mathrm{K}$;

$\mathrm{m}$ - number of data pairs of enthalpy and entropy;

$\mathrm{T}_{\mathrm{hm}}$ - harmonic mean temperature, $\mathrm{K}$, and

$\mathrm{n}$ - number of temperatures used. 


\section{RESULTS AND DISCUSSION}

Tables 1 and 2 display the water activity data estimated by the Chung-Pfost model (Equations 1 and 2) at temperatures of $10,20,30,40$ and $50{ }^{\circ} \mathrm{C}$, and equilibrium moisture content ranging from 2.60 to $21.50 \%$ (d.b.) for desorption and from 2.00 to $20.60 \%$ (d.b.) for adsorption. These data were used to determine the differential enthalpy and entropy of sorption of rice in the husk.

TABLE 1. Water activity values (decimal) for desorption, estimated by the Chung-Pfost model, as a function of temperature and equilibrium moisture content of rice in the husk

\begin{tabular}{|c|c|c|c|c|c|}
\hline \multirow{2}{*}{$\mathrm{U}_{\mathrm{e}}(\%$ d.b. $)$} & \multicolumn{5}{|c|}{ Temperature $\left({ }^{\circ} \mathrm{C}\right)$} \\
\hline & 10 & 20 & 30 & 40 & 50 \\
\hline 2.60 & 0.0115 & 0.0218 & 0.0352 & 0.0512 & 0.0689 \\
\hline 4.70 & 0.0412 & 0.0651 & 0.0917 & 0.1197 & 0.1482 \\
\hline 5.50 & 0.0605 & 0.0905 & 0.1223 & 0.1546 & 0.1865 \\
\hline 6.50 & 0.0916 & 0.1292 & 0.1670 & 0.2039 & 0.2392 \\
\hline 7.20 & 0.1181 & 0.1605 & 0.2020 & 0.2414 & 0.2784 \\
\hline 8.00 & 0.1528 & 0.2001 & 0.2449 & 0.2865 & 0.3248 \\
\hline 8.90 & 0.1967 & 0.2484 & 0.2959 & 0.3389 & 0.3778 \\
\hline 10.10 & 0.2615 & 0.3170 & 0.3662 & 0.4096 & 0.4480 \\
\hline 10.20 & 0.2671 & 0.3229 & 0.3721 & 0.4155 & 0.4538 \\
\hline 11.40 & 0.3366 & 0.3936 & 0.4425 & 0.4846 & 0.5211 \\
\hline 11.80 & 0.3602 & 0.4171 & 0.4655 & 0.5069 & 0.5427 \\
\hline 12.20 & 0.3838 & 0.4404 & 0.4881 & 0.5288 & 0.5637 \\
\hline 12.30 & 0.3897 & 0.4461 & 0.4937 & 0.5342 & 0.5689 \\
\hline 13.70 & 0.4710 & 0.5248 & 0.5690 & 0.6060 & 0.6372 \\
\hline 15.60 & 0.5740 & 0.6217 & 0.6599 & 0.6912 & 0.7173 \\
\hline 16.00 & 0.5942 & 0.6403 & 0.6772 & 0.7073 & 0.7323 \\
\hline 17.50 & 0.6642 & 0.7044 & 0.7361 & 0.7617 & 0.7828 \\
\hline 18.10 & 0.6896 & 0.7274 & 0.7571 & 0.7809 & 0.8005 \\
\hline 18.90 & 0.7212 & 0.7558 & 0.7829 & 0.8045 & 0.8223 \\
\hline 21.50 & 0.8062 & 0.8315 & 0.8510 & 0.8665 & 0.8790 \\
\hline
\end{tabular}

TABLE 2. Water activity values (decimal) for adsorption, estimated by the Chung-Pfost model, as a function of temperature and equilibrium moisture content of rice in the husk.

\begin{tabular}{|c|c|c|c|c|c|}
\hline \multirow{2}{*}{$\mathrm{U}_{\mathrm{e}}(\%$ d.b. $)$} & \multicolumn{5}{|c|}{ Temperature $\left({ }^{\circ} \mathrm{C}\right)$} \\
\hline & 10 & 20 & 30 & 40 & 50 \\
\hline 2.00 & 0.0128 & 0.0237 & 0.0377 & 0.0542 & 0.0724 \\
\hline 4.10 & 0.0247 & 0.0418 & 0.0620 & 0.0843 & 0.1078 \\
\hline 5.00 & 0.0433 & 0.0676 & 0.0945 & 0.1226 & 0.1511 \\
\hline 5.80 & 0.0697 & 0.1017 & 0.1351 & 0.1685 & 0.2012 \\
\hline 6.50 & 0.1043 & 0.1437 & 0.1829 & 0.2207 & 0.2565 \\
\hline 7.10 & 0.1469 & 0.1928 & 0.2366 & 0.2775 & 0.3152 \\
\hline 8.00 & 0.1964 & 0.2475 & 0.2943 & 0.3369 & 0.3755 \\
\hline 9.00 & 0.2514 & 0.3058 & 0.3543 & 0.3973 & 0.4355 \\
\hline 9.20 & 0.3098 & 0.3659 & 0.4146 & 0.4569 & 0.4940 \\
\hline 10.20 & 0.3700 & 0.4261 & 0.4737 & 0.5145 & 0.5497 \\
\hline 10.70 & 0.4302 & 0.4849 & 0.5305 & 0.5690 & 0.6018 \\
\hline 11.00 & 0.4888 & 0.5411 & 0.5840 & 0.6197 & 0.6500 \\
\hline 11.10 & 0.5448 & 0.5938 & 0.6336 & 0.6663 & 0.6938 \\
\hline 12.60 & 0.5973 & 0.6426 & 0.6789 & 0.7086 & 0.7333 \\
\hline 14.50 & 0.6458 & 0.6871 & 0.7199 & 0.7466 & 0.7686 \\
\hline 15.30 & 0.6900 & 0.7273 & 0.7567 & 0.7804 & 0.7999 \\
\hline 16.00 & 0.7299 & 0.7633 & 0.7893 & 0.8102 & 0.8274 \\
\hline 17.20 & 0.7656 & 0.7952 & 0.8181 & 0.8365 & 0.8515 \\
\hline 18.00 & 0.7972 & 0.8232 & 0.8434 & 0.8594 & 0.8725 \\
\hline 20.60 & 0.8250 & 0.8479 & 0.8654 & 0.8794 & 0.8907 \\
\hline
\end{tabular}


As expected, increases in equilibrium moisture contents led to an increased water activity. The same trend was observed by increasing temperatures, for both processes (desorption and adsorption) (Tables 1 and 2). Similar results were found by Oliveira et al. (2013b), who studied the thermodynamic properties of corn under different moisture contents and at $10,20,30$, and $40{ }^{\circ} \mathrm{C}$.

Figure 1 reveals the observed and estimated values of differential enthalpy as a function of equilibrium moisture content. In order to acquire the $\Delta \mathrm{H}$ of rice in the husk, the value of $\Delta \mathrm{H}_{\text {vap }}$ was added to the values of $\Delta \mathrm{H}$. The value of $\Delta \mathrm{H}_{\text {vap }}$ was calculated at $30^{\circ} \mathrm{C}$, which is the mean temperature used in this study resulting in a value of $2406.60 \mathrm{~kJ} \mathrm{~kg}^{-1}$.

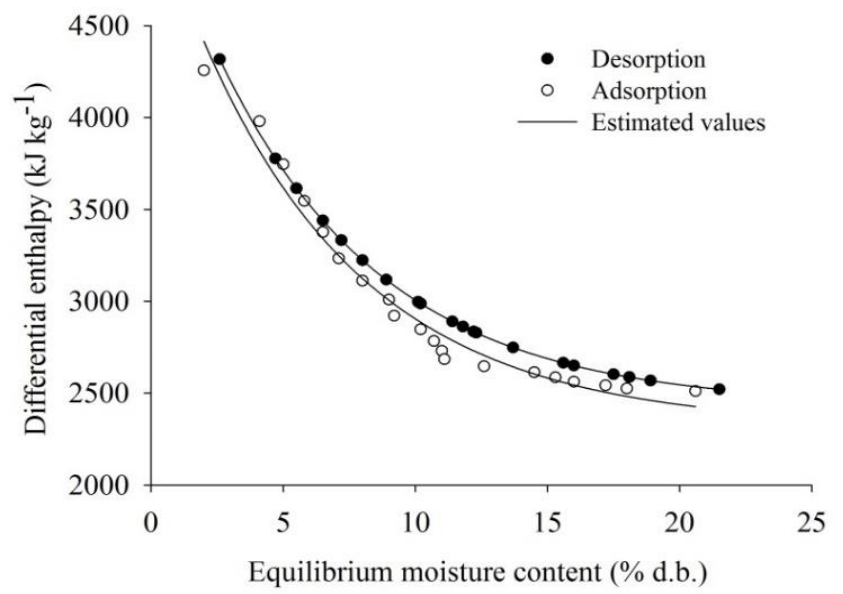

FIGURE 1. Observed and estimated values of differential enthalpy of desorption $(\Delta \mathrm{H})$ and adsorption of rice in the husk.

Figure 1 shows that the differential enthalpy increased exponentially with equilibrium moisture content reduction, being more pronounced at a moisture content below $10 \%$ (d.b.). The same trend was observed by Ascheri \& Bastos (2015), who investigated the thermodynamic properties of adsorption of two red rice genotypes.

A high integral isosteric heat of sorption at low water contents can be explained by the different bonding strength between water and the adsorbent surface of a product. At initial stages of sorption, there are polar sorption sites highly active with elevated interaction energy on the adsorbent surface, which is covered with water molecules forming a monomolecular layer (AlMuhtaseb et al., 2004). As the water molecules become chemically bonded to the highly active sorption sites, sorption begins to occur at less active sites (higher moisture content), presenting a low interaction energy and, consequently, a lower integral isosteric heat of sorption (Wang \& Brenan, 1991).

For a constant moisture, the values of integral isosteric heat of desorption are higher than those of adsorption, indicating a large amount of energy required for desorption to the detriment of the adsorption process. These results are similar to those found by Vega-Gálvez et al. (2014), who assessed the desorption and adsorption isotherms of cape gooseberry. The higher values of isosteric heat of desorption indicate a larger number of polar sites or sorption sites at the adsorbent surface of a product when compared to the adsorption process (Mcminn \& Magee, 2003).

According to McMinn \& Magee (2003), knowing the values of integral isosteric heat of sorption, at a specific moisture content, enables the checking of the status of water molecules adsorbed to the product. Furthermore, these values show the physical, chemical, and biological stability of a food under certain storage conditions. While the integral isosteric heat of desorption varied between 4316.99 and $2521.44 \mathrm{~kJ} \mathrm{~kg}^{-1}$ for a moisture range from 2.6 to $21.5 \%$ (d.b.), the integral isosteric heat of adsorption ranged from 4256.53 to $2511.03 \mathrm{~kJ} \mathrm{~kg}^{-1}$ within a moisture range of 2.0 to $20.6 \%$ (d.b.).

Figure 2 demonstrates the observed and estimated values of differential entropy of desorption and adsorption $(\Delta \mathrm{S})$ as a function of equilibrium moisture content.

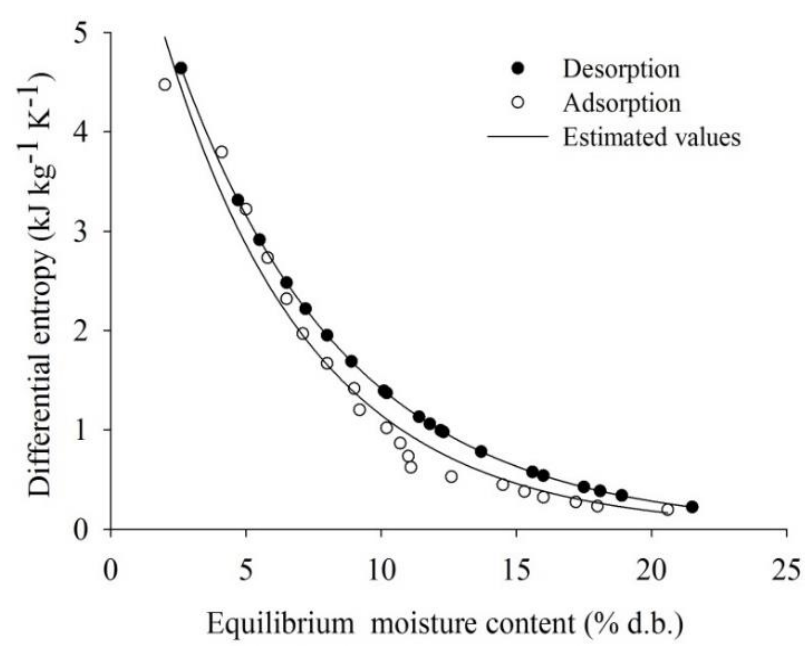

FIGURE 2. Observed and estimated values of differential entropy of desorption and adsorption of rice in the husk, as a function of equilibrium moisture content.

Through Figure 2, one can note that differential entropy had a similar trend as the integral isosteric heat of sorption regarding equilibrium moisture content variation. Such behavior was expected since entropy generation is conditioned to heat transfer between two systems, being its magnitude always proportional to the heat transferred at a given temperature. That being stated, as the heat transferred during desorption is higher than that during adsorption process, the magnitudes of differential entropy of desorption are higher. This phenomenon was observed by various researchers for several products, such as sesame seed (Kaya \& Kahyaoglu, 2006), okra seeds (Goneli et al., 2010), Jatropha curcas seeds (Oliveira et al., 2014), forage turnip seeds (Souza et al., 2015) and rice grain (Corrêa et al., 2017).

According to Al-Muhtaseb et al. (2004), the differential entropy of a food material is proportional to the number of sites available to sorption at a certain energy level. As adsorption occurs, water molecules occupy the active sites, decreasing the entropies associated with the sites still available. Aviara et al. (2004) stated that low water contents cause loss of the rotational movement of water molecules as sites begin to saturate and, as a result, the differential entropy decreases with an increasing equilibrium water content. 
As stated before, the differential entropy of desorption is higher than that of adsorption process (Figure 2 ). Hence, in agreement with the aforementioned theory, it could be affirmed that the results found in the present study indicate a higher mobility of water molecules during desorption compared to adsorption. These results are in accordance with those found by Goneli et al. (2016), who studied the thermodynamic properties of water sorption of castor beans.

According to the second law of thermodynamics, a process is reversible when the sum of entropy changes of the entire subsystems of a process is constant (Madamba et al., 1996). Since desorption and adsorption of rice in the husk are real and involve heat transfer, entropy is generated in both processes.

The differential entropy of desorption varied between 4.64 and $0.22 \mathrm{~kJ} \mathrm{~kg}^{-1} \mathrm{~K}^{-1}$ for a moisture range of 2.6 to $21.5 \%$ (d.b.), whereas for adsorption it ranged from 4.47 and $0.20 \mathrm{~kJ} \mathrm{~kg}^{-1} \mathrm{~K}^{-1}$ under a moisture range of 2.0 to $20.6 \%$ (d.b.).

Figures 3 and 4 present the observed and estimated values of Gibbs free energy as a function of equilibrium moisture content of rice in the husk for both desorption and adsorption, respectively.

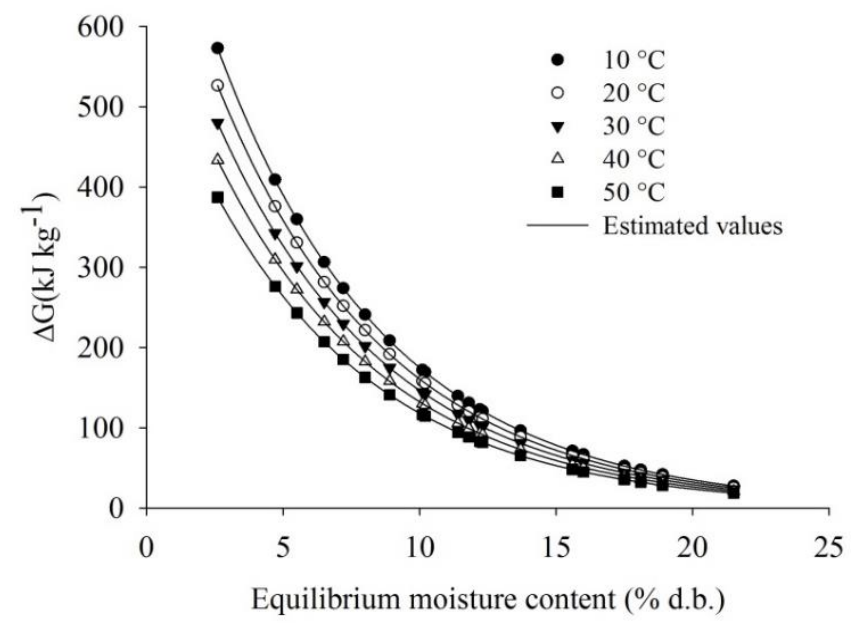

FIGURE 3. Observed and estimated values of Gibbs free energy $(\Delta G)$ for desorption of rice in the husk, as a function of equilibrium moisture content.

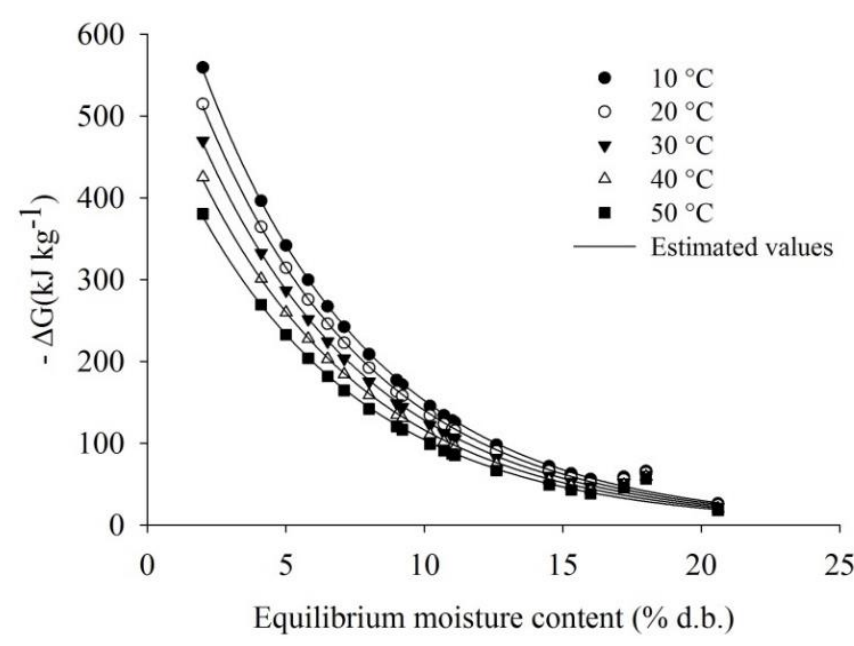

FIGURE 4. Observed and estimated values of Gibbs free energy $(\Delta G)$ for adsorption of rice in the husk, as a function of equilibrium moisture content.
From the thermodynamic point of view, the Gibbs free energy of a product expresses the affinity between the solid matrix of a food material and the water. It indicates the spontaneity $(\Delta \mathrm{G}<0)$ or non-spontaneity $(\Delta \mathrm{G}>0)$ of a sorption process (McMinn et al., 2005).

Analyzing Figures 3 and 4, one can verify that the Gibbs free energy values are positive for desorption and negative for adsorption, indicating that the former is endothermic, whilst the later is exothermic. This trend is expected since adsorption is spontaneous. Initially, samples of rice in the husk had a lower equilibrium relative humidity and then, during storage, being submitted to a higher relative humidity until equilibrium. Conversely, in the desorption case, the process is characterized for being non-spontaneous, i.e. samples of rice in the husk were initially found with higher equilibrium relative humidity, being afterward submitted to a lower relative humidity until equilibrium.

Figures 3 and 4 clarify that the Gibbs free energy decreased as the temperature rose, in both processes. It can be explained by the higher degree of molecules movement accelerating mass exchange, thus speeding up the process. Costa et al. (2016), studying the thermodynamic properties of jaboticaba peel during the drying process at temperatures of $40,50,60$, and $70{ }^{\circ} \mathrm{C}$, also found the same result. Nevertheless, the influence of temperature at higher moisture contents becomes irrelevant since the sorption sites at these humidity levels are already available (Goneli et al., 2013).

Figure 5 presents the linear relationship between differential enthalpy and entropy of sorption for both desorption and adsorption processes. The enthalpy and entropy values were calculated for each experimental value of equilibrium moisture content.

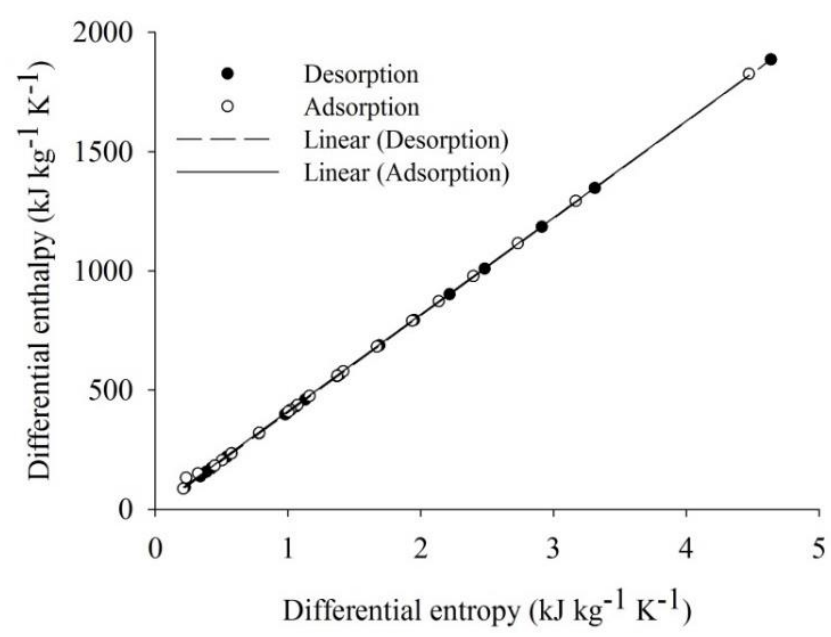

FIGURE 5. Enthalpy-entropy relationship for water desorption and adsorption in rice in the husk.

Since there was a high degree of linearity $\left(\mathrm{R}^{2}>99 \%\right)$ between differential enthalpy and entropy of both sorption processes, the enthalpy-entropy compensation theory (or isokinetic theory) can be considered valid for the water sorption phenomena of rice in the husk.

To validate the aforementioned theory, the isokinetic temperature must be compared to the mean harmonic temperature (Equation 7). According to Krug et al. (1976a; 1976b), the existence of linear chemical compensation is confirmed if the isokinetic temperature is 
different from the mean harmonic temperature. The isokinetic temperatures for desorption and adsorption of rice in the husk were 406.50 and $408.19 \mathrm{~K}$, respectively. The mean harmonic temperature calculated was $302.50 \mathrm{~K}$, which is significantly different from all isokinetic temperatures described above, thus confirming the enthalpy-entropy compensation theory for water sorption of rice in the husk.

According to Liu \& Guo (2001), the isokinetic temperature is the one at which reactions in a sequence must occur simultaneously, i.e. at equilibrium. At the present study, the isokinetic temperatures were similar for desorption and adsorption processes, suggesting that, for rice in the husk, the energy exchanges tend to happen at the same proportion in both processes, when the product is in equilibrium with the air. When studying potatoes and other substances rich in starch, McMinn et al. (2005) concluded that the microstructure of these materials is stable, and do not undergo significant alterations during water sorption.

The water sorption process of agricultural products may be controlled by enthalpy or entropy. According to Leffer (1955), such process is controlled by enthalpy if $T_{B}$ $>\mathrm{T}_{\mathrm{hm}}$, and by entropy, if $\mathrm{T}_{\mathrm{B}}<\mathrm{T}_{\mathrm{hm}}$. Since the first condition was found here, the water sorption mechanism of rice in the husk is enthalpy controlled. This result is in agreement with those found by several researchers (Goneli et al., 2013; Martinez-Monteagudo \& Salais-Fierro, 2014; Nicoleti et al., 2015; Silva et al., 2015; Oliveira et al., 2017).

\section{CONCLUSIONS}

A reduction of equilibrium moisture content of rice in the husk leads to an increase in the energy required for water removal from this product, being represented by the integral isosteric heat of desorption; whereas an increase in the energy released by the adsorption process can be represented by the integral isosteric heat of adsorption. The values of integral isosteric heat of desorption are higher than those of adsorption, at a given equilibrium moisture content.

This reduction of equilibrium moisture content also leads to an increment in the differential entropy of desorption and adsorption; and, for the same equilibrium moisture content, the differential entropy of desorption is higher than adsorption.

The Gibbs free energy decreased with increasing temperatures in both processes. The values of this parameter were positive for desorption and negative for adsorption, indicating that the former is endothermic, whilst the later is exothermic.

The enthalpy-entropy compensation theory, or isokinetic theory, can be satisfactorily applied to the sorption phenomena of rice in the husk, being desorption and adsorption processes controlled by enthalpy.

\section{ACKNOWLEDGEMENTS}

The authors would like to thank the Coordenação de Aperfeiçoamento Pessoal de Nível Superior - CAPES (Coordination for the Improvement of Higher Education Personnel) for the essential support and financial aid in the form of Master's degree scholarship.

\section{REFERENCES}

Al-Muhtaseb AH, McMinn WAM, Magee TRA (2004)

Water sorption isotherms of starch powders. Part 2: Thermodynamic characteristics. Journal of Food Engineering 62:135-142.

Ascheri DPR, Bastos SMC (2015) Propiedades de adsorción de água de dos genótipos de arroz rojo. Engenharia Agrícola 35:134-143.

Aviara NA, Ajibola OO, Oni SA (2004) Sorption equilibrium and thermodynamic characteristics of soya bean. Biosystems Engineering 87:179-190.

Brasil (2009) Regras para análises de sementes. Brasília, Ministério da Agricultura e Reforma Agrária, Secretaria Nacional de Defesa Agropecuária, 399p.

Corrêa PC, Oliveira GHH, Oliveira APLR, Botelho FM, Goneli ALD (2017) Thermodynamic properties of drying process and water absorption of rice grains. CyTA Journal of Food 15:204-210.

Corrêa PC, Oliveira GHH, Oliveira APLR, Vargas-Elías GA, Baptestini FM (2016) Particle size and roasting on water sorption in conilon coffee during storage. Coffee Science 11:221-233.

Corrêa PC, Oliveira GHH, Santos ES (2012)

Thermodynamic properties of agricultural products processes. In: Arana I, (ed). Physical properties of foods: novel measurement techniques and applications. CRC Press, p131-141.

Costa CF, Corrêa PC, Vanegas JDB, Baptestini FM, Campos RC, Fernandes LS (2016) Mathematical modeling and determination of thermodynamic properties of jabuticaba peel during the drying process. Revista Brasileira de Engenharia Agrícola e Ambiental 20:576580.

Goneli ALD, Corrêa PC, Oliveira GHH, Afonso Júnior PC (2013) Water sorption properties of coffee fruits, pulped and green coffee. LWT - Food Science and Technology 50:386-391.

Goneli ALD, Corrêa PC, Oliveira GHH, Botelho FM (2010) Water desorption and thermodynamic properties of okra seeds. Transaction of the ASAE 53:191-197.

Goneli ALD, Corrêa PC, Oliveira GHH, Oliveira APLR,; Orlando RC (2016) Moisture sorption isotherms of castor beans. Part 2: Thermodynamic properties. Revista Brasileira de Engenharia Agrícola e Ambiental 20:757762.

Kaya S, Kahyaoglu T (2006) Influence of dehulling and roasting process on the thermodynamics of moisture adsorption in sesame seed. Journal of Food Engineering 76:139-147.

Krug RR, Hunter WG, Grieger RA (1976a) Enthalpyentropy compensation. 1 - Some fundamental statistical problems associated with the analysis of Van't Hoff and Arrhenius data. Journal of Physical Chemistry 80:23352341 . 
Krug RR, Hunter WG, Grieger RA (1976b) Enthalpyentropy compensation. 2 - Separation of the chemical from the statistical effect. Journal of Physical Chemistry 80:2341-2351.

Lima CVS, Hoehne L, Meurer EJ (2015) Cádmio, cromo e chumbo em arroz comercializado no Rio Grande do Sul. Ciência Rural 45:2164-2167.

Liu L, Guo QX (2001) Isokinetic relationship, isoequilibrium relationship, and enthalpy-entropy compensation. Chemical Reviews 101:673-695.

Madamba PS, Driscoll RH, Buckleb KA (1996) The thinlayer drying characteristics of garlic slices. Journal of Food Engineering 29:75-97.

Martinez-Monteagudo SI, Salais-Fierro F (2014) Moisture sorption isotherms and thermodynamic properties of Mexican Mennonite-style cheese. Journal of Food Science and Technology 51:2393-2403.

McMinn WAM, Al-Muhtaseb AH, Magee TRA (2005) Enthalpy-entropy compensation in sorption phenomena of starch materials. Journal of Food Engineering 38:505-510.

McMinn WAM, Magee TRA (2003) Thermodynamic properties of moisture sorption of potato. Journal of Food Engineering 60:157-165.

Mingotte FLC, Hanashiro RH, Filho DF (2012)

Características físico-químicas do grão de cultivares de arroz em função da adubação nitrogenada. Semina: Ciências Agrárias 33:2605-2618.

Moreira R, Chenlo F, Torres MD, Vallejo N (2008) Thermodynamic analysis of experimental sorption isotherms of loquat and quince fruits. Journal of Food Engineering 88:514-521.

Nicoleti JF, Alves TP, Fóz HD (2015) Isotermas de dessorção de pimentão verde e energia envolvida no processo. Brazilian Journal of Food Technology 18:137145 .

Oliveira GHH, Corrêa PC, Oliveira APLR, Reis RCR, Devilla IA (2017) Application of GAB model for water desorption isotherms and thermodynamic analysis of sugar beet seeds. Journal of Food Process Engineering 40:1-8.

Oliveira DEC, Resende O, Bessa JFV, Kester NA (2013a) Kinetic and thermodynamic properties of soybean grain during the drying process. Journal of Agricultural Engineering 44:331-337.
Oliveira DEC, Resende O, Chaves TH, Sousa KA, Smaniotto TAS (2014) Propriedades termodinâmicas das sementes de pinhão-manso. Bioscience Journal 30:147157.

Oliveira DEC, Resende O, Smaniotto TAS, Sousa KA, Campos RC (2013b) Propriedades termodinâmicas de grãos de milho para diferentes teores de água. Pesquisa Agropecuária Tropical 43:50-56.

Resende O, Oliveira DEC, Chaves THC, Bessa JFV (2014) Kinetics and thermodynamic properties of the drying process of sorghum (Sorghum bicolor [L.] Moench) grains. African Journal of Agricultural Research 9:24532462.

Rizvi SSH (1995) Thermodynamic properties of foods in dehydration. In: Rao MA, Rizvi SSH (eds). Engineering properties of foods. Academic Press, p223-309.

Shafaei SM, Masoumi AA, Roshan H (2016) Analysis of water absorption of bean and chickpea during soaking using Peleg model. Journal of the Saudi Society of Agricultural Sciences 15:135-144.

Silva CLOC, Faria LJG, Costa CML (2015)

Comportamento higroscópico de partes aéreas de pimentade-macaco (Piper aduncum L.). Revista Brasileira de Engenharia Agrícola e Ambiental 19:376-381.

Souza KA, Resende O, Goneli ADL, Smaniotto TAS, Oliveira DEC (2015) Thermodynamic properties of water desorption of forage turnip seeds. Acta Scientiarum Agronomy 37:11-19.

Vega-Gálvez A, López J, Ah-Hen K, Torres MJ, LemusMondaca R (2014) Thermodynamic properties, sorption isotherms and glass transition temperature of cape gooseberry (Physalis peruviana L.). Food Technology and Biotechnology 52:83-92.

Walter M, Marchezan E, Avila LA (2008) Arroz: composição e características nutricionais. Ciência Rural 38:1184-1192.

Wang N, Brennan JG (1991) Moisture sorption isotherm characteristics of potato at four temperatures. Journal of Food Engineering 14:269-287. 